\title{
THE PROBLEM OF UNPAID WORK IN HOUSEHOLD IN THE CONTEXT OF EVOLUTION OF CONTEMPORARY SOCIOECONOMIC THOUGH
}

\begin{abstract}
The issue of valuation of home work performed in a household in the context of its remuneration raises a lot of controversy. Unpaid work done for a household by members of the society, often in society, is not considered valuable at all. As it appears, however, it is also a kind of limitation of basic human rights regarding remuneration for the work done or the right to rest. The aim of the article is to stimulate reflection on the issue of unpaid work and its role in the contemporary economy, as well as to indicate the directions of changes in the approach of economists in the treatment of unpaid work in households.
\end{abstract}

Keywords: household, unpaid work, critical economy, socioeconomic though.

\section{INTRODUCTION}

The contemporary economy emphasizes the lack of due consideration of the role of the household in socio-economic development. This charge applies not only to sociological but also economic frameworks. In households, care and home work (paid and unpaid) are invisible and undervalued despite the fact that they are the basis for the development of economies and societies. The household, after all, is the "creator" of human capital. In this context, it is emphasized that in a market economy, putting as a priority the criterion of high productivity rather than "creating" human capital contradicts the ideas of humanism. Unpaid work recognized as unpaid work is rarely seen as important in socio-economic development or as an activity that helps satisfy social needs in the broadly understood sphere of services.

The problem of unpaid work in a household is a multidimensional phenomenon. It can be considered from various research perspectives. The most common aspect is the aspect of the division of roles in the household. Here the problem is treated as an effect of the existence of rules defining the relations of men and women in social life. In the new household economy, research more and more often refers to the microeconomic level, including the division of roles and unpaid work of women.

The aim of the article is to stimulate reflection on the issue of unpaid work and its role in the modern economy, as well as to indicate the directions of changes in the approach of economists in the treatment of unpaid work in households.

\footnotetext{
${ }^{1}$ Małgorzata Leszczyńska, PhD, Department of Macroeconomics and International Relations, Faculty of Economics, University of Rzeszow, ul. M. Ćwiklińskiej 2, 35-601 Rzeszow; phone: 17 872-17-17; e-mail: leszczczynska.malgorzata@wp.pl. ORCID: 0000-0002-8117-8788.
} 
The sphere of the household, and in particular of unpaid work in this farm (reproductive and protective), and in general its socio-economic self-agency, until recently was not at all the issues considered within the framework of economic sciences. The sphere of the household, and in particular of unpaid work in this farm (reproductive and protective), and in general its socio-economic efficiency, until recently was not at all the issues considered within the framework of economic sciences.

Contrary to the fact that in historical terms in the household his members have always worked for him, this work was completely invisible to economists (Szwarc, Żarnowska, 2000). However, this approach has fundamentally changed, as evidenced by the evolution of modern economic thought.

Unpaid work can be any kind of work provided free of charge, which has no formal basis (defined in the applicable legal system), from which no mandatory burdens are paid (Compare the causes..., 2008). The performance of unpaid work is considered an area of private agreements between household members, and therefore involves compliance with obligations arising from the nature of its provision, is voluntary, selfless or enforced by mechanisms of reciprocity.

\section{AN UNPAID WORK IN FEMINIST TREND - EVOLUTION APPROACH}

In the 1960s and 1970s, for the first time, the issue of the working environment, which is a household, was formulated, focusing on the specifics of the work of people in this household (but in particular only those who do not work professionally). Earlier, the attention of social scientists was focused solely on the budgets of working time of economically active people. Such an approach meant that the phenomenon of work in the household became even more invisible, and did not require any change or scientific recognition. It is worth noting that the first attempts to price household work by Polish researchers, such as A. Hodoly, L. Zienkowski or L. Szczerbińska, were undertaken only at the end of the 1970s and in the 1980s (Lapniewska, 2019).

It is worth noting that economics, despite being part of the social sciences, for many years overlooked these important social aspects in research models and methods. They were based primarily on mathematics, which was to determine the scientific objectivity of this discipline. In the conducted research, the issues of the human psyche, identity, historical context and cultural circle were not taken into account, which strongly influenced adopted principles of management in a given place and time (Cagatay, Elson, 2000).

Modern economics is an interdisciplinary trend, combining economics with elements of sociology, political science, anthropology, psychology and other related sciences. The subject of the article refers mainly to feminist currents related to neoclassical economics and the so-called critical economy (Elson, Jain, 2011). However, they are characterized by a different approach. Neoclassical economics refers mainly to the situation of women in the labor market and inequalities in the professional space (it is connected with the concepts ie: glass ceiling, sticky floor or pay gap), but it does not question the assumptions of the neoliberal system itself. Meanwhile, the critical economy ${ }^{2}$ emphasizes the lack of consideration of the role of women and their care and home work (paid and unpaid) in the current macroeconomic framework, despite the fact that they form the basis for the development of

\footnotetext{
2 The trends of critical economy include radical economics represented by N. Folbre, H. Hartmann and A. Picchio, and institutional economics headed by the first Nobel Prize winner in economics E. Ostrom, and A. Jennings.
} 
economies and societies. In addition, this trend shows that these works are invisible and undervalued. According to her, categories based on mathematical modeling used by orthodox trends in economics are too narrow to present a full picture of phenomena taking place in the economy, especially those of a socio-economic nature.

As indicated in the introduction, until recently, work in the household remained beyond the interest of the mainstream of social sciences, including economics. Homework included what unfinished work became only the main area of interest in the so-called feminist economists who used analysis tools drawn from neoclassical economics (Dijkstra, Plantenga, 2003). Some of the researchers (Ferber, Nelson, 1993) concluded that the development of orthodox theory, based on microeconomic principles, showing social reality using mathematical tools, is insufficient. They indicated that in the scientific discourse of economics and in macro-economic systems of measuring the potential of the economy, only the activities of market economy entities are disseminated and analyzed. Therefore, activities performed as part of households excluded them from the beginning from theoretical approaches of economics. The important justification of the socio-economic role of households was not taken into account, especially that without their paid or unpaid work, mainly of a caring nature, not only enterprises but also the entire economy could not function (Łapniewska, 2019).

In the classical economics tradition there is a division into the so-called production and non-productive work. The former is performed on the basis of an employment relationship and is referred to as "productive", the other is work for the benefit of the household. This division also applies to remuneration for performing these works. The production work is carried out for a fee, while work for the household free. This puts the household in which most of the so-called unproductive works are performed, in a situation of marginalization in socio-economic life. A wide range of activities performed in a household is treated as resulting from family roles, and therefore natural. These activities are generally defined as duties and not as household work.

To broaden the concept of productive labor with reproductive labor contributed especially the two economic trends: the trend of radical economics and the trend of institutional economics. Although in today's economy there are different approaches to the unpaid work in the household, it can be noticed the compatibility of them on several fundamental points of departure ${ }^{3}$. It is worth noting that the common point of reference, especially for the critical trends in economics, were strictly defined essential assumptions and postulates. Proposals are aimed at redefining the work beyond the definition of only production work, and thus treating it more broadly, that is, as a caring, reproductive or emotional work. It is also important to treat unpaid housework and care as the basis of all socio-economic systems and to include them in macroeconomic analyzes. The consequence of this approach is to place at the heart of the considerations people connected with each other and dependent on each other, not an isolated individual (Gideon, 1999). There is also important the analysis of the relationship between the formal economy or the market as a mechanism of monetary exchange and the care economy, where people's lives are maintained, as well as barter, for their own needs or for the natural economy.

It is emphasized that it is necessary to take into account the perspective of social reproduction, i.e. the biological reproduction of life, as well as the reproduction of culture (inter

\footnotetext{
${ }^{3}$ It is worth noting that the common point of reference, especially for the critical trends in economics, were strictly defined essential assumptions and postulates.
} 
alia by socialization) and the economic role of social reproduction in creating added value (Compare..., 2006). It is important to point out that human activity is important. Therefore, not only economic results should be evaluated, but also processes. It also means questioning power and unequal access to it (Albelda, 2002).

Attention should also be paid to assessing the relationship between the material dimension of life and social development, demographic determinants, social institutions, such as the market or family, as well as the development of scientific economic thought in these areas and its practical effects. It seems important to analyze programs based on neo-liberal foundations, in terms of their social effects, as well as a set of assumptions in conducting economic and social policy by states as well as by supranational organizations (Robeyns, 2014). In turn, the adoption as a starting point that economic success should be measured by the well-being and the quality of people's lives is currently a priority. This approach suggests that it should be related to the distribution of income and wealth, personal rights and freedoms and the satisfaction of heterogeneous human needs (Aslaksen, Flaatten, Koren, 1999). In addition, it is important to recognize the importance of your values. In this respect, it is emphasized that ethical opinions are justified (Beneria, 2003; Robeyns, 2003; Nussbaum, 2003; Łapniewska, 2017), unavoidable and necessary in economic analyzes. These priorities should also combine the interdisciplinary approach of scientific works within the economy, taking into account the philosophical, sociological or political perspective. In the feminist critique of economics, it is emphasized that unpaid homework as a reproductive or caring work, i.e. work devoted to maintaining and recreating people's lives, concerns women. Unpaid housework, because of the traditional division of time, work and social roles by gender, is performed mainly by women. It is emphasized that this is not just a matter of valorisation of free work and the quality of women's life, but also the question of social reproduction and the relationship between the market, where the production of goods and services is organized as well as the reproduction of capital and households, where consumption takes place, as well as the reproduction of culture and the ability of people to work is maintained (Łapniewska, 2018). The market can not function without the reproductive and emotional work of women for the biological and cultural reproduction of people (ie the so-called socialization). According to some researchers, reproductive work ${ }^{4}$ on raising a child (pregnancy, childbirth, care) is part of the overall economy of management.

\section{A NEW ECONOMICS OF HOUSEHOLD AND ALTERNATIVE MODELS}

Nowadays in economics, in the field of unpaid work, alternatives to the mainstream economics are sought. One of such alternative postulates is the construction of a theoretical model that will show the real and more "human" picture of the economy. Feminist economists, looking for alternatives to mainstream economics, propose a so-called circular model of the market extended by a welfare economy (reproductive). According to this approach,

\footnotetext{
${ }^{4}$ It should be added here that also the biological determinants of women's life (pregnancy and lactation) are an additional burden on the woman's body. In this connection, the feminist critical economy indicates that reproduction related to pregnancy, delivery and lactation is also work.
} 
it is assumed that in such a model the starting point should not be an increase in money flows through the economy, but securing the needs ${ }^{5}$ and foundations for life (Power, 2004).

In the new household economics, the relationship between the social and economic policy of the state and the level and quality of life in households is noticeable. Policies formulated on the basis of Keynesian economics assume the division of reproductive labor costs between the state and households ${ }^{6}$. On the other hand, policies based on assumptions derived from the theory of neoclassical economics of supply, monetarism, or neoclassical household economics transfer the responsibility for reproduction and maintenance of people's lives to the household and its family as an economic and reproductive unit. For households, this means increasing family maintenance costs, and the necessary work either is done free of charge at home, or the needs are met in the form of goods and services purchased on the market or through their informal activities. According to the study of time budgets, women are responsible for the majority of activities related to household reproduction.

Taking this into account, it is worth noting that such a burden means deterioration of their quality of life, especially considering the fact that most women combine paid work and free homework ${ }^{7}$. In addition, financial crises, more flexible forms of employment, and employment instability, reduction of social transfers translate into a greater burden on women. Some scholars question the neoclassical assumption of women's infinitely flexible working time, referring to the buffer function of the welfare economy and its exhaustion (Łapniewska, 2019). Following the visualization of the role of reproductive labor, there has been developed the criticism of the market model in neoclassical economics which assumes that the market functions as a system of circulating exchange of goods and money between households and enterprises. It is particularly emphasized that this model narrows the understanding of the economy only to the market as a monetary exchange system, and also ignores the wider area of economic activity of economic entities, including households, and the role of their work for their own needs. In addition, this model omits the role of the welfare economy or the natural environment. An important caveat of the neoclassical model

${ }^{5}$ It is worth emphasizing that these issues are also interested in the outstanding contemporary economist - Nobel Prize winner in economics A. Sen. See (Sen, 1999). Development as free-house, Oxford.

${ }^{6}$ It is about universal healthcare, social insurance, free education, low-paid pre-school care and for older people, or subsidized housing for low-income groups.

${ }^{7}$ Comprehensive quantitative and qualitative research conducted in Poland indicated that men spend a week at work by 9.45 hours longer than women, but they spend 45 hours more on household homework and childcare. Economists also pay attention to gender differences and the division of roles in creating the well-being of households. In this respect, it was noticed that the economic contribution of women to production is grossly underestimated in traditional statistical analyzes, as women perform about $2 / 3$ of all household work on household, and domestic work accounts for $60-80 \%$ of the total value of home production. It is worth noting, however, that this critical trend of economics omits somehow the participation of men in providing unpaid labor in a household, which is a limitation of these theories. Men, in particular from middle-income and low-income households, also deal with unpaid work for households. Estimates indicate that this applies to $30 \%-40 \%$ of the global value of this work. In recent years, however, the attitude of both women (from traditional to assertive) and men, who more and more often accept the so-called an affiliate system in which they must take over part of the reproductive and care work. It gives you the opportunity to negotiate a more just gender contract (Górnicka-Boratyńska, 2005; Pszczółkowska, 2019). 
is also the fact that it omits the role of institutions, and thus all forms of knowledge, social norms, regulations that define and reproduce certain assumptions about management methods, social relations, as well as relations between people or between them and nature (Elson, 2015). It can be stated that the market economy and its monetary exchange is to a large extent based on reproductive, caring and free work in the household, which, however, is not reflected in the macroeconomic accounts.

New household economics in explaining the role of unpaid labor in the economy proposes to refer to the theory of human capital ${ }^{8}$. It is worth noting that in the modern world, social relations take place under the influence of institutions that significantly limit the choice of individuals. The theory of human capital focuses on individual decisions, ignoring the influence of others on these decisions. Similarly, radical economics indicates that education, which in the theory of human capital is to increase the potential of individuals and their remuneration in the labor market, in fact allows to divide people into less and more talented and is only a method of adapting workers to the needs of the capitalist economy ${ }^{9}$. Formulating the theory of rational economic behavior based on hierarchical dualisms also excludes women who are attributed to altruistic behaviors and the political duty of maternity care. At the same time, the modern economic order is built on the exclusion of care work.

In the critical economy, the assumptions about exogenous or immutable preferences as well as rational and selfish entities are being undermined. Taking into account these problems, the proposals of economists are heading towards reformulating the definition of economics. The point is that the definition of economics, as a science of decision making, which derives from the theory of rational choice, should be replaced with a definition describing it as a science of satisfying needs, because this approach more fully reflects not only the subject of interest in this field of science, but also the main subject socio-economic life, which is a household.

Similarly, the criticism of efficiency is because what is economically efficient can be inefficient from a social perspective ${ }^{10}$. Rejection of a narrow definition of effectiveness indicates that work in the sense of producing added value can only be effective when it refers to "production of life" or production for own needs, which takes place primarily within the framework of free work in the household (Charkiewicz, 2009).

It is worth noting that the unpaid performance of many activities in the household is treated as a natural attribute of its members' roles (Titkow, Duch-Krzystoszek, Budrowska, 2004). It also turns out that the activities performed for the household can be attributed to various professions (Mikuta, 2000). This indicates not only the large variety of tasks, but also the versatility that is required of a person considered "non-working" (Zachorowska-Mazurkiewicz, 2010) which deals with running a household.

An interesting conceptual approach is also a manifesto for a more just life formulated by F. Haug. Her proposals in this respect are aimed at dividing the sixteen-hour day of general work into various forms of human activity, including four areas: gainful employ-

\footnotetext{
${ }^{8}$ However, so-far the theory of human capital is limited to activity on the labor market, not taking into account the aspect of its creation or its interaction in households, or more broadly in the society.

${ }^{9}$ In this respect, feminist economics criticizes the view of people as rational, autonomous and focused only on their own benefit. This trend points to dualisms: self-benefit and the benefit of others, rationality and emotionality or separation and connection.

${ }^{10}$ It can even be said that the more efficiency, the more pressure is directed towards the welfare economy.
} 
ment, reproduction, personal development and political activity. It is postulated to fairly redistribute the work so that every person can devote 4 hours to each dimension of life (Haug, 2011). This ideal model of the whole work day could change the labor market relations by reducing the time of work, which in the situation of excess supply of jobs in relation to the demand for it, would help to alleviate the problem of unemployment and insecurity on the labor market. In addition, each member of the household would be involved in reproductive work, that is, all the work necessary for the regeneration of civil society, and therefore not only works for the home and family. It is claimed that this would solve the problem of payment for performing housework. In addition, the estimation of the economic dimension of homework could be used to include years of service, in which household members dealt with the home, children and dependent persons, constituting the basis for calculating the retirement pension. It is worth emphasizing that in the literature on the subject in this respect, the views of researchers are still very divided.

Nevertheless, there is no doubt that everyday activities related to the provision of unpaid work in households should be supported by the state, which through services rendered (nurseries, kindergartens, assistance in the care of the elderly and disabled) would relieve households and their members. It also seems that unpaid work should be included in the broader framework of macroeconomics so that they are recognized on an equal footing with market-oriented production and service work. Nowadays, unpaid work performed for households can also be treated as a public good, which benefits from macro-generation in the form of a reconstructed workforce.

\section{CONCLUSION}

Only in the last two decades of the 21 st century, thanks to quantitative and qualitative research, the so-called critical economy related to the feminist trend and the assumptions of the new household economy, activities were undertaken to define the role and assessment of the relationship between paid work and unpaid work in the household. A significant share in the activities performed for the household is the work of women in the household called "unpaid work" or "unpaid services". Giving prestige to work done in the household and breaking with the theory of division of labor into production and non-productive (not adding value) led not only to the renegotiation of the sex contract. It is extremely important, however, that this led, at least on theoretical grounds, to the increasing recognition of both reproductive and nursing work as equivalent to paid work.

It is also important to determine the size of home production in public statistics, because it would allow for an objective determination of the real level of labor inputs of women and men in households as an element that is the basis for regulation in the social policy, in particular family and pension policy.

The important thing is that while the approach to unpaid work has not changed in practical terms, including - at the level of macroeconomic measurement of the economy - it is the theoretical ground that positive progress in this field is visible.

\section{REFERENCES}

Albelda, R. (2002). Fallacies of Welfare-to-Work Policies [In:] Albelda, R., Withorn, A., eds., Lost Ground: Welfare Reform, Poverty, and Beyond, Boston: South End Press.

Aslaksen, I., Flaatten, A., Koren, Ch. (1999). Explorations on Economics and Quality of Life. "Feminist Economics”, 5(2). 
Beneria, L. (2003). Gender, Development, and Globalization: Economics as if People Mattered. London: Routledge .

Cagatay, N., Elson, D. (2000). The Social Content of Macroeconomic Policies. "World Development", Vol. 28, No. 7.

Charkiewicz, E., Zachorowska-Mazurkiewicz, A. (2009). Feminist Dictionary of Economics Concepts, Online Library of Think Tank Feminist [Access: 8.03.2019]. Access on the Internet: https://rownosc.info/bibliography/publication/feministyczny-slownik-pojec-z-ekonomii; https://rownosc.info/dictionary/ekonomia-feministyczna/.

Compare the causes of undeclared work, its scale, character and social consequences. Final report on research. (2008). Warsaw: CBOS, IPiSS.

Compare Unpaid homework - how to treat it, to effectively form the basis of a caring society? (2006). Report, Łódź: Institute of Civil Affairs.

Dijkstra, A.G., Plantenga, J., ed. (2003). Economics and gender. The occupational position of women in the European Union. Gdańsk: GWP.

Elson, D. (2015). Women's empowerment and environmental sustainability in the context of international UN agreements [In:] Hawley, J., Why women will save the planet. London: Zed Books.

Elson, D., Jain, D. (2011). Zbieranie feministycznej wiedzy na potrzeby odbudowy postępów polityki publicznej. Kalifornia, Ottawa: New Delhi Thousand Oaks, Międzynarodowe Centrum Badań Rozwoju SAGE.

Ferber, M., Nelson, J., eds., (1993). Beyond Economic Man: Feminist Theory and Economics. Chicago: University Press.

Gideon, J. (1999). Looking at Economies as Gendered Structures: An Application to Central America. "Feminist Economics", No. 5(1).

Górnicka-Boratyńska, A., Women's homework - should it be payable?, Interview with A. Titkow and D. Duch-Krzystoszek. "Gazeta Wyborcza”, 23.04.2005.

Haug, F. (2011). Perspective four in one. Manifesto for a more just life. Translator M. Boyer, M. Skóra. Online Library of Think Tank Feminist [Access: 8.03.2019]. Access on the Internet: http://www.ekologiasztuka.pl/pdf/f0107haug.pdf.

Łapniewska, Z. (2017). Ethics of caring and the economy of the future. "Theoretical Practice", No. 2 (24).

- (2018). Epistemology of Feminist Economics [In:] Giorgino, V., Walsh, Z., eds., CoDesigning Economies in Transition. Cham: Palgrave Macmillan.

- (2019). Unpaid work of women, Online Library of the Think Tank Femini-stycznia [Access: 20.03.2019]. Access on the Internet: //rownosc.info/bibliography/publication/feministycznyslownik-pojec-z-ekonomii.

Mikuta, B. (2000). Studies on the value of homework in the city and in the countryside, with particular emphasis on the implementation of the nutritional function, PhD thesis. Warsaw: SGGW.

Nussbaum, M. (2003). Capabilities as Fundamental Entitlements: Sen and Social Justice. "Feminist Economics" 9(2/3).

Power, M. (2004). Social Provisioning as a Starting Point for Feminist Economics. "Feminist Economics" 10(3), November.

Pszczółkowska, D. (2019). Male and female homework [Access: 8.03.2019]. Access on the Internet: https://wyborcza.pl. 
Robeyns, I. (2003). Sen's Capability Approach and Gender Inequality: Selecting Relevant Capabilities. "Feminist Economics", 9 (2/3).

(2014). Ingrid Robeyns - Will basic income give justice to women ?, transl. M. Szlinder. Theoretical Practice, 10 February [Access: 15.03.2019]. Access on the Internet: http://www. praktykateoretyczna.pl/?s=Robeyns.

Sen, A. (1999). Development as freedom. Oxford.

Szwarc, A., Żarnowska, A. (2000). Równe prawa i nierówne szanse. Warszawa: Wydawnictwo DiG.

Titkow, A., Duch-Krzystoszek, D., Budrowska, B. (2004). Unpaid work of women. Myths, realities, perspectives. Warsaw: IFIS PAN.

Zachorowska-Mazurkiewicz, A. (2010). Recovering citizenship. Macroeconomic analysis of the situation of women in Poland. Online Library of Think Tank Feminist 2010.

DOI: $10.7862 /$ rz.2019.hss.28

The text was submitted to the editorial office: April 2019.

The text was accepted for publication: September 2019. 
